\title{
Influence of Polyvinyl Alcohol on Corrosion Resistance of Mild Steel Simulated Concrete Pore Solution Prepared in Well Water
}

\author{
T. SHANTHI ${ }^{1}$ and S. RAJENDRAN ${ }^{2}$ \\ ${ }^{1}$ P.G. Department of Chemistry, \\ Srinivasan College of Arts and Science, Perambalur-621212, India \\ ${ }^{2}$ Department of Chemistry, \\ RVS School of Engineering and Technology, Dindigul, India \\ shanchem23@gmail.com
}

Received 28 July 2013 / Accepted 30 August 2013

\begin{abstract}
Corrosion resistance of mild steel in simulated concrete pore solution (SCPS) prepared in well water in the absence and presence of polyvinyl alcohol (PVA) and $\mathrm{Zn}^{2+}$ has been evaluated by weight loss method. It was observed that when PVA is added the corrosion inhibition efficiency (IE) increases. As the concentration of PVA increases, inhibition efficiency also increases. Addition of $\mathrm{Zn}^{2+}$ improves of IE further. 50 ppm of PVA has $50 \%$ IE. 100 ppm of PVA shows $90 \%$ IE. When $50 \mathrm{ppm}$ of $\mathrm{Zn}^{2+}$ was added to the above system, both system shows 94\% IE. The mechanistic aspects of corrosion inhibition have been studied using AC impedance spectra. The scanning electron microscopy (SEM) study confirms the protection of mild steel surface by strong adsorption of PVA.
\end{abstract}

Keywords: Concrete corrosion, Simulated concrete pore solution, Mild steel, Polvinyl alcohol

\section{Introduction}

Corrosion is the destruction of metals and alloys by chemical and electro chemical reaction with its environment. It is a natural phenomenon which cannot be avoided, but it can be controlled and prevented using appropriate techniques like metallic coating, anodic protection, cathodic protection and using inhibitors etc. Inhibitors have very good role in the presence of corrosion inhibition. The organic inhibitors contain hetero atom like oxygen, nitrogen, sulphide and phosphorous. It shows better corrosion efficiency of the compounds containing hetero atom follows $\mathrm{O}<\mathrm{N}<\mathrm{S}<\mathrm{P}^{1,2}$. Application of polymers as corrosion inhibitors have been attracted several researchers ${ }^{3,4}$. Corrosion inhibition by conducting polymer has been studied ${ }^{5}$. The use of polymers as corrosion inhibitors has attracted considerable attention. Polymers such as poly (vinyl pyrolidone), poly ethylamine, polyaniline, polysiloxane and polyethylene glycol methyl ether, have been widely reported ${ }^{6-13}$. The application of 
water soluble polymers as corrosion inhibitors of metal in different media has been cited. The inhibition efficiency of poly(vinyl alcohol) in controlling the corrosion of mild steel was investigated $^{14-16}$. The inhibitors such as poly (vinyl alcohol) and polyethylene glycol were found to obey Temkin, Freundlich and Frumkin adsorption isotherm from the fit of the experimental data ${ }^{17}$. A saturated solution of calcium hydroxide is used as simulated concrete pore solution ${ }^{18,19}$. The aim of the present study is to investigate the corrosion resistance of mild steel in simulated concrete pore solution in presence of polyvinyl alcohol and $\mathrm{Zn}^{2+}$ combination to mild steel in well water. The physicochemical parameters of the well water taken in preset study are given Table 1 . The corrosion inhibition efficiency was collected using weight loss, polarization and AC impedance studies. The protective film formed on the metal surface characterized using morphological studies such as scanning electron microscopy (SEM).

Table 1. Parameters of well water

\begin{tabular}{cc}
\hline Parameter & Value \\
\hline $\mathrm{pH}$ & 8.38 \\
Conductivity & $3110 \mu \mathrm{mhos} / \mathrm{cm}$ \\
TDS & $2013 \mathrm{ppm}$ \\
Chloride & $665 \mathrm{ppm}$ \\
Sulphate & $14 \mathrm{ppm}$ \\
Total hardness & $1100 \mathrm{ppm}$ \\
\hline
\end{tabular}

\section{Experimental}

Mild steel specimen was used in the present study (Composition (wt\%):0.026 S, 0.06\% P, $0.4 \% \mathrm{Mn}, 0.1 \% \mathrm{C}$ and balance iron $^{20}$ ) of the dimensions $1.0 \times 4.0 \times 0.2 \mathrm{~cm}$ were polished to a mirror finish and decreased with trichloroethylene and used for the weight loss method.

\section{Simulated concrete pore solution (SCPS)}

A saturated calcium hydroxide solution was used in the present study, as SCP solution. The electrodes made of mild steel wire were immersed in the SCP solution and AC impedance spectra was carried out.

\section{Mass-loss method}

Mild steel specimens in triplicate were immersed in $100 \mathrm{~mL}$ of simulated concrete pore solution (SCPS) containing various concentrations of the inhibitor in the presence and absence of $\mathrm{Zn}^{2+}$ for one day. The weight of the specimens before and after immersion was determined using Shimadzu balance, model AY 210. The corrosion products were cleansed with Clarke's solution ${ }^{21}$. Then the inhibition efficiency (I.E.) was then calculated using the equation (1)

$$
\text { I.E }=100[1-(\mathrm{W} 2 / \mathrm{W} 1)] \%
$$

Where, $W_{1}$ and $W_{2}$ are the corrosion rates in the absence and presence of the inhibitor, respectively. The corrosion rate (CR) was calculated using the formula (Eq. 2)

$C R=$ [(Weight loss in $\mathrm{mg}$ ) / (Area of the specimens in $\mathrm{dm}^{2} \mathrm{x}$ immersion period in days) mdd (mdd $=$ mg/decimeter/day)

\section{AC impedance spectra}

The instrument used for polarization study was used to record AC impedance spectra also. The cell set up was the same. The real part $\left(\mathrm{Z}^{1}\right)$ and imaginary part $\left(\mathrm{Z}^{11}\right)$ of the cell impedance 
were measured in ohms at various frequencies. The values of the charge transfer resistance $\left(\mathrm{R}_{\mathrm{t}}\right)$ and the double layer capacitance $\left(\mathrm{C}_{\mathrm{dl}}\right)$ were calculated.

\section{Surface examination study}

The mild steel specimens were immersed in various test solutions for a period of one day. After one day the specimens were taken out and dried. The nature of film formed on the surface of metal specimens was analysed by surface analysis technique, SEM.

\section{Scanning electron microscopy}

The mild steel specimens immersed in various test solutions for one day were taken out, rinsed with double distilled water, dried and subjected to the surface examination. The surface morphology measurements of the mild steel surface were carried out by scanning electron microscopy (SEM) using HITACHI -S-3000H SEM.

\section{Results and Discussion}

\section{Analysis of weight loss study}

The calculated inhibition efficiencies (IE) and corrosion rates (CR) PVA in controlling corrosion mild steel immersed in simulated concrete pore solution in the absence and presence of $\mathrm{Zn}^{2+}$ ion are given in Table 2. The calculated value indicates the ability of PVA to be a good corrosion inhibitor. PVA alone shows some IE, but the combination of PVA $50 \mathrm{ppm}$ and $\mathrm{Zn}^{2+} 50 \mathrm{ppm}$ shows $94 \%$ IE. This suggests a synergitic effect exists between PVA and $\mathrm{Zn}^{2+}$ ion.

Table 2. Inhibition efficiencies (IE\%) and corrosion rates (CR) obtained from PVA-Zn ${ }^{2+}$ system, when mild steel immersed in saturated concrete pore solution prepared in well water

\begin{tabular}{clc}
\hline System & IE \% & $C R$ mdd \\
\hline 50 ppm PVA & 50 & 19.5 \\
100 ppm PVA & 90 & 3.9 \\
50 ppm PVA+Zn ${ }^{2+} 50 \mathrm{ppm}$ & 94 & 2.3 \\
$100 \mathrm{ppm}$ PVA $+\mathrm{Zn}^{2+} 50 \mathrm{ppm}$ & 94 & 2.3 \\
\hline
\end{tabular}

\section{Analysis of AC impedance spectra}

AC impedance spectra of mild steel immersed in simulated concrete pore solution prepared in well water in the absence and presence of inhibitor and $\mathrm{Zn}^{2+}$ are shown in the Figures 1 to 2. The Nquist plots are shown in Figure 1. The Bode plots are shown in Figures 2a and $2 b$. The charge transfer resistance $\left(\mathrm{R}_{\mathrm{t}}\right)$ and double layer capacitance $\left(\mathrm{C}_{\mathrm{dl}}\right)$ values are derived from Nquist plots. Impedance values, $\log (\mathrm{z} / \mathrm{ohm})$ are derived from Bode plots. The results are summarized in Table 3.

Table 3. Impedance parameters of metals immersed in simulated concrete pore solution prepared in well water, obtained by AC impedance spectra

\begin{tabular}{cccc}
\hline \multirow{2}{*}{ System } & \multicolumn{2}{c}{ Nquist plot } & \multirow{2}{*}{$\begin{array}{c}\text { Bode plot } \\
\log \text { z/ohm }\end{array}$} \\
\cline { 2 - 3 } & $R_{\mathrm{t}}$ ohm. $\mathrm{cm}^{2}$ & $C_{\mathrm{dl}} \mathrm{Fcm}^{-2}$ & \\
\hline $\begin{array}{c}\text { SCPS (blank) } \\
\text { SCPS + 50 ppm PVA } \\
+50 \mathrm{ppm} \mathrm{Zn}^{2+}\end{array}$ & 3045 & $6.305 \times 10^{-9}$ & 3.4 \\
\hline
\end{tabular}




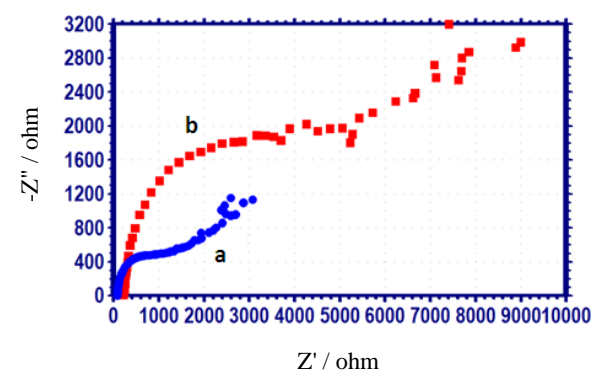

Figure 1. AC impedance spectrum of mild steel immersed in various test solution; (a) SCPS (blank) (b) SCPS + PVA $50 \mathrm{ppm}+\mathrm{Zn}^{2+} 50 \mathrm{ppm}$ (Nquist plot)
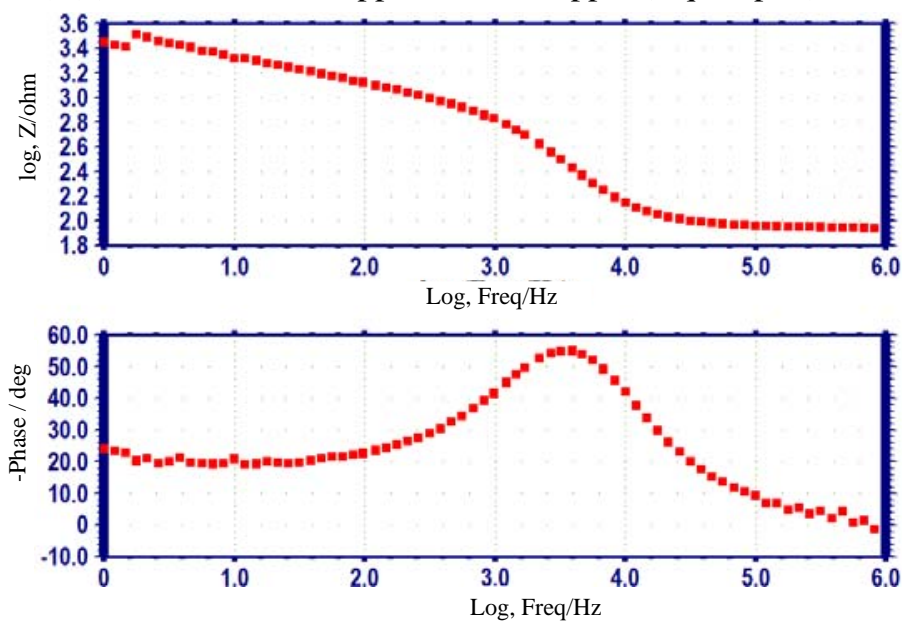

Figure 2a. AC impedance spectrum of mild steel immersed in SCPS (Bode plot)
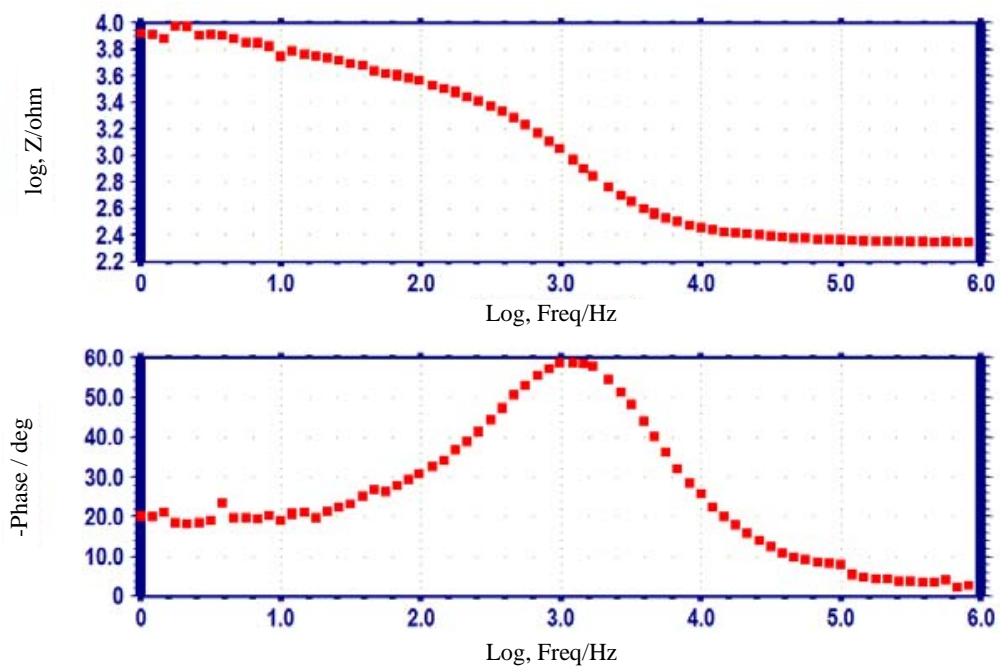

Figure 2b. AC impedance spectrum of mild steel immersed in SCPS + PVA 50 ppm Zn ${ }^{2+} 50$ ppm (Bode plot) 
When corrosion rate of a metal decreases due to formation of protective film, the charge transfer resistance value increases and double layer capacitance value decreases, the impedance value $\log (\mathrm{z} / \mathrm{ohm})$ increases ${ }^{18-26}$. It is observed from Table 3, the $R_{t}$ value 3045 ohm. $\mathrm{cm}^{2}$, the $\mathrm{C}_{\mathrm{dl}}$ Value is $6.305 \times 10^{-9} \mathrm{~F} \mathrm{~cm}^{-2}$ and the impedance value is $3.4 \log (\mathrm{z} / \mathrm{ohm})$. When 100 ppm PAA and 50ppm $\mathrm{Zn}^{2+}$ are added to above the solution. The $\mathrm{R}_{\mathrm{t}}$ value $8951 \mathrm{ohm}$. $\mathrm{cm}^{2}$ increases, the $C_{\mathrm{dl}}$ Value is $2.145 \times 10^{-9} \mathrm{~F} \mathrm{~cm}^{-2}$ decreases and the impedance value is 4.0 $\log (\mathrm{z} / \mathrm{ohm})$ increases. The increases charge transfer resistance $\left(\mathrm{R}_{\mathrm{t}}\right)$ value, the double layer capacitance $\left(C_{\mathrm{dl}}\right)$ value decreases and the impedance value $(\mathrm{z})$ increases. This confirms the formation of protective film formed on the metal surface. This accounts for the better inhibition efficiency of the PVA $-\mathrm{Zn}^{2+}$.

\section{Scanning electron microscopy}

SEM provides a pictorial representation of the surface. To understand the nature of the surface film in the absence and presence of inhibitors and the extent of corrosion of mild steel, the SEM micrographs of the surface examined. The SEM micrograph (X 1000) of a polished mild steel surface (Control) in Figure 3(a) shows the smooth surface of the metal. This shows the absence of any corrosion products or inhibitor complex formed on the metal surface. The SEM micrographs (X 1000) of mild steel specimen immersed in the SCPS for one day is shown in Figure 3(b) and Figure 3(c) respectively.

The SEM micrographs of mild steel surface immersed in the SCPS is shown in Figure 3(b). This shows the roughness of the metal surface which indicates the corrosion of mild steel in SCPS. The Figure 3(c) indicates that in the presence of $50 \mathrm{ppm}$ PVA and $50 \mathrm{ppm} \mathrm{Zn}^{2+}$ mixture in SCPS, the surface coverage increases which in turn results in the formation of insoluble complex on the metal surface. In the presence of PVA and $\mathrm{Zn}^{2+}$, the surface is covered by a thin layer of inhibitors which effectively control the dissolution of mild steel ${ }^{27}$.

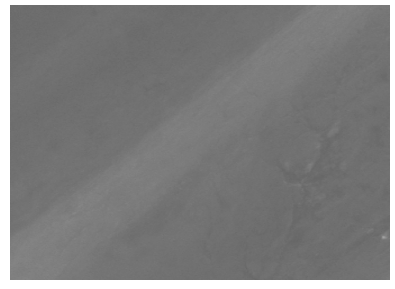

(a)

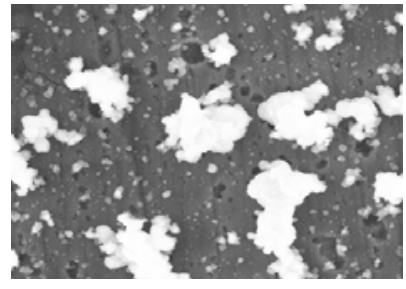

(b)

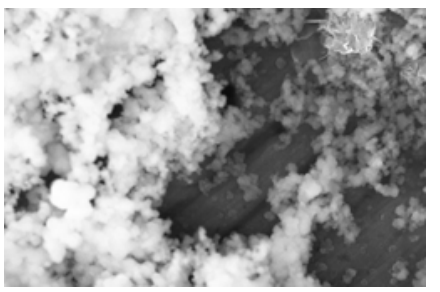

(c)

Figure 3. SEM analysis of a) Polished mild steel (control); b) mild steel immersed in SCPS(Blank); c) mild steel immersed in SCPS + + PVA $50 \mathrm{ppm}+\mathrm{Zn}^{2+} 50 \mathrm{ppm}$

\section{Conclusion}

The inhibition efficiency (IE) of polyvinylalcohol (PVA) in controlling corrosion of mild steel immersed in simulated concrete pore solution prepared in well water in the absence of $\mathrm{Zn}^{2+}$ has been evaluated by weight loss method. The formulation consisting of $50 \mathrm{ppm}$ PVA and $50 \mathrm{ppm} \mathrm{Zn}^{2+}$ has $94 \%$ corrosion inhibition efficiency. AC impedance spectra reveals that a protective film is formed on the metal surface. The SEM micrographs confirm the formation of protective layer on the metal surface.

\section{Acknowledgement}

The authors are thankful to their management and university grants commission, India, for the help and encouragement. 


\section{References}

1. Doneelly B D, Downie T C, Grzeskowaik R, Hamburg H R and Short D, Corros Sci., 1997, 38, 109.

2. Subramaniam N C, Shesadri B S and Mayanna S M, Corros Sci., 1993, 34(4), 563-571.

3. Umoren S A, Ogbobe O, Igwe I O and Ebenso E E, Corros Sci., 2008, 50(7), 1998-2006.

4. Umoren S A, Solomon M M, Udosoro I I and Udoh A P, Corros Sci., 2010, 52(4), 1317-1325.

5. Gelling V J, Wiest M M, Dennis E T, Bierwagen G P and Wallace G G, Pro Org Coatings , 2001, 43(1-3), 149-157; http://dx.doi.org/10.1016/S0300-9440(01)00186-2

6. Wang H, Niu L, Hong Q,Su X Wu and Feng Hua Wei, Chin Chem Lett., 2004, 15, 486-496.

7. Herrasti P, Ocon P, Ibanez A and Fatas E, J Appl Electrochem., 2003, 33(6), 533-542.

8. Le D P, Yoo Y H, Kim J G, Cho S M and Son Y K, Corros Sci., 2009, 51(2), 330-338; http://dx.doi.org/10.1016/j.corsci.2008.10.028

9. Finsgar M, Fassbender S, Nicolini F and Milosev I, Corros Sci ., 2009, 51(3), 525533; http://dx.doi.org/10.1016/j.corsci.2008.12.006

10. Jianguo Y, Lin W, Otieno- Alego V and Schweinsberg D P, Corros Sci., 1995, 37(6), 975-985; http://dx.doi.org/10.1016/0010-938X(95)00008-8

11. Schweinsberg D P, Hope G A, Trueman A and Otieno- Alego V, Corros Sci., 1996, 38(4), 587-599; http://dx.doi.org/10.1016/0010-938X(95)00148-D

12. Azioune A, Marcozzi M , Revello V and Pireaux J-J, Surf Interface Anal., 2007, 39, 615-623.

13. Dubey A K and Sing G, Port Electrochim Acta., 2007, 25, 221-235.

14. Rajendran S, Sridevi S P, Anthony N, John Amalraj A and Sundravadivelu M, Anti Corros Meth Mater., 2005, 52, 102-111; DOI:10.1108/00035590510584816

15. Umoren S A, Ebenso E E, Okafor P C and Ogbobe O, Pigment Resin Tech., 2006, 35, 346-354; DOI:10.1108/03699420610711353

16. Umoren S A, Ogbobe O, Ebenso E E and Ekpe U J, Pigment Resin Tech, 2006 35, 284-291; DOI:10.1108/03699420610692896

17. Umoren S A, Ebenso E E, Okafor P C, Ogbobe O and Ekpe U J, J Appl Polym Sci, 2007,103, 2810-2819; DOI:10.1002/app.25446

18. Allaharam S R and Khodayari M, Anti-Corros Methods Mater., 2008, 55, 250.

19. Mennucci M M, Banczek E P, Rodrigues P R P and Coasta I, Cement Concrete Compos., 2009, 418(28), 31.

20. Arocia Selvi J, Rajendran S, Garga Srin V, John Amalraj A and Narayanaswamy B, Port Electrocheim Acta, 2009, 27, 1-11; DOI:10.4152/pea.200901001

21. Wranglen G, Introduction to corrosion and protection of metals (Chapman and Hall, London), 1985, 236.

22. Leema Rose A, Noreen Antony, Felicia Rajarnmal Selva Rani A, Peter Pascal Regis and Rajendran S, Zastit Mater., 2009, 50, 167.

23. Rajendran S, Kanagamani M, Sivakalaivani M, Jeyasundari J, Narayanasamy B and Rajam K, Zastita Mater., 2008, 49, 19.

24. Sathiyabama J, Rajendran S, Arocia Selvi J and Jeyasundari J, Open Corros J., 2009, 2, 77-82; DOI:10.2174/1876503300902009077

25. Agnesia Kanimozhi S and Rajendran S, Int J Electrochem Sci., 2009, 4(3), 353-388.

26. Kalaivani R, Narayanasamy B, Selvi J A, Amalraj A J, Jeyasundari J and Rajendran S, Port Electrocheim Acta, 2009, 27(2), 177-187; DOI:10.4152/pea.200902177

27. Samide A, Ciuciu A and Negrila C, Port Electrocheim Acta, 2010, 28(6), 385-396. 